\title{
SEDIMENTARY FACIES AND DEPOSITIONAL ENVIRONMENTS OF CENOZOIC SEDIMENTARY FORMATIONS CROPPING OUT AT THE CENTRAL PART OF THE DOUALA BASIN
}

\author{
1,2 Bachirou Mfayakouo Chavom, ${ }^{3}$ Pierre R. Njike Ngaha and ${ }^{4}$ Dieudonné L. Bitom \\ ${ }^{1}$ Department of Earth Sciences, Faculty of Science, University of Maroua, B.P. 814, Cameroon \\ ${ }^{2}$ Department of Earth Sciences, Faculty of Science, University of Yaoundé I, Cameroon \\ ${ }^{3}$ Department of Earth Sciences, Faculty of Science, University of Dschang, Cameroon \\ ${ }^{4}$ Department of Earth Sciences, Faculty of Science, University of Ngaoundere, Cameroon
}

Received 2014-07-16; Revised 2014-07-25; Accepted 2014-08-11

\begin{abstract}
The Douala Basin is one of three units of the Cameroonian coastal basin in the Gulf of Guinea, formed from the east-west extension between African and South American plates generated during the opening of South Atlantic in the Early Cretaceous. This basin contains sediments from Lower Cretaceous to present. The Cretaceous depositional environments are well understood whereas there is very little information concerning Cenozoic depositional environments. Facies and their stratigraphical distribution analyses were conducted on Cenozoic formations exposed at the E-W central part of the Douala Basin in the Missole II, Piti, Missole I and Dibamba localities, with an objective to provide details on the depositional environments and to reconstruct the depositional model and their evolution over time. Seventeen (17) lithofacies were identified on the basis of lithology, grain size and sedimentary structures. The facies constitute three (3) main facies associations; the gravelly dominated, the sandy dominated and the fine grained dominated. These facies and facies associations were interpreted and five depositional environments successions were recognized; the fluvial-braided and meandered channel, the delta plain, the continental shelf and the marginal-littoral. The facies distribution shows a progradational succession from a fluvial to delta plain at the axial part of the basin and a storm dominated continental shelf to marginal-littoral at the central part of the basin. The facies stacking patterns depict sedimentation mainly controlled by sag subsidence and probably by climate.
\end{abstract}

Keywords: Cenozoic Formations, Facies, Depositional Environments, Sag Subsidence, Douala Basin

\section{INTRODUCTION}

The Douala Basin is a part of West African basins formed during the opening of the South Atlantic and located in the Gulf of Guinea (Fig. 1a). This basin records sediment from early Cretaceous to recent. Knowing about the environments of the Douala Basin is crucial to better understand the evolution of the West African margin. Discovery of petroleum from Cretaceous sediments have been focused many studies on this period in the Douala Basin and some studies have been carried out on specific aspect of the basin since the mid-1960s by (Reyre, 1966; Belmonte, 1966; Dumort, 1968; Regnoult, 1986).

These studies concern the structure and the stratigraphy of Douala Basin. Salard (1977; 1979; 1981) also detailed the Late Cretaceous and Cenozoic palynoflora and biostratigraphy of the basin based on data from Kwa-Kwa well. As part of petroleum research, Nguene et al. (1992; Loule et al., 1997) used data synthesis from eight oil wells to describe the paleoenvironmental evolution of the Douala and Kribi/Campo Basin and Mbesse et al. (2012) established a Palaeocene-Eocene boundary of the

Corresponding Author: Bachirou Mfayakouo Chavom, Department of Earth Sciences, Faculty of Science,

University of Maroua, B.P. 814, Cameroon 
Douala Basin based on palynostratigraphic analysis performed on four wells core samples.

However, outcrops have rarely been studied with the exception of the Cretaceous and Early Palaeocene characterized by (Njike Ngaha, 1984; 2005; Njike Ngaha and Eno Belinga, 1987; Ntamak et al., 2003; Kenfack et al., 2012; Oliver and Petters, 2013). The application of sedimentological analysis has, in the past, been very limited in the Douala Basin, especially on Cenozoic outcrops and studies to date devoted only to very briefly different sedimentological processes during this period. On the other hand, these outcrops are generally scarce, occur as small sections and are sometimes weathered in places. This may explain why geological information from this period in the Douala Basin, especially evolution of its depositional environment, is still very scanty.

The main objective of this study was to provide details on lithofacies evolution, the depositional environments of Douala Basin during the Cenozoic and their depositional model evolution over time by presenting field observation data and interpretation. Our study will consist in the description of facies association and their depositional process and facies succession cropping out in the E-W central part of the Douala Basin. These preliminary studies are important for palaeogeographic understanding of Cenozoic sedimentation in the Douala Basin in its relation to similar formations within the West African margin.

\section{GEOLOGICAL AND TECTONOSEDIMENTARY SETTING}

The Douala Basin is a large epicontinental and structural depression found in the Gulf of Guinea (Fig. 1a). It has a roughly triangular shape; its maximum width occurs around the vicinity of the Mount Cameroon volcanic massif, which limits it to the northwest. In the east, it is limited by Precambrian basement and to the west it extends under the Gulf of Guinea Sea. Hedberg (1969; Delteil et al. (1975) estimate that there are links between the tectonic evolution and sedimentary sequences in the basins of the West African coast from Angola to Cameroon. Regarding the Cameroonian coastal basins, Benkhelil et al. (2002) differentiated three major tectonic episodes driving sediment dynamics. This is the syn-rift phase, the drift I and II phases. These conclusions have been later confirmed in the Douala Basin by Manga (2008).
The syn-rift phase (Barremian-Aptian): This phase begins before the effective separation of the two continents, with morphology comparable to that currently observed in the East African rift valleys (Logar, 1983; Rosendahl and Scott, 1989). This phase begins in the Douala basin in the Aptian to Albian by narrow tectonic trough. The majority of the sediments encountered and described by (Reyre, 1966; Dumort, 1968; Njike Ngaha, 1984; Regnoult, 1986) are of continental fluvial or lacustrine origin and consist essentially of polygenic and polymictic conglomerates with some interbedded sandstones and shales (Fig. 2). These deposits are named "basal sandstones" or Mundeck formations by (Nguene et al., 1992; Pauken, 1992; Meyers et al., 1996; Ntamak et al., 2010) and are characterized by syntectonic deformations.

The drift I phase (Aptian-Eocene): It is characterized by several tectono-sedimentary events including the E-W extension and faulted subsidence. This phase corresponds to open ocean accompanied by evaporite deposits (absent in Douala Basin) whose cycle end is marked by marine sediments which testify to the opening of the South Atlantic.

During this phase, the Douala Basin recorded marl, clay and limestone deposits subsequent to the global Cenomanian-Turonian transgression demonstrated by (Reyre, 1966; Dumort, 1968; Regnoult, 1986; Njike Ngaha, 1984; 2005). The drift I phase is also marked in the basin by a regressive period, due to falling sea level. This regressive episode created an erosional unconformity surface at the base of the Upper Cretaceous (Fig. 2) which was later succeeded by lacustrine deposits of the Logbadjeck (Cenomanian-Campanian) and Logbaba (Maastrichtian) formations and marine deposits of the N'kapa (Palaeocene-Eocene) formations highlighted by (Nguene et al., 1992; Coward et al., 1999).

The drift II phase (Eocene to Recent): The Douala Basin during Eocene was marked by a regressive tendency with flexure and resumption of erosion on the emerged margin. This intensive erosion on the margin created an unconformity on which were deposited formations consisting of black or brown clay with some small sandy bars, clayey sands interbedded with thin limestone, sand and gravel alternating with plastic clays (Fig. 2). These deposits are named Souellaba (Oligocene) and Matanda (Miocene) formations by Nguene et al. (1992). During the Late Miocene to Recent, there has been a general regression, followed by the establishment of new deltaic units of detrital materials, most of which contain volcanic elements. 


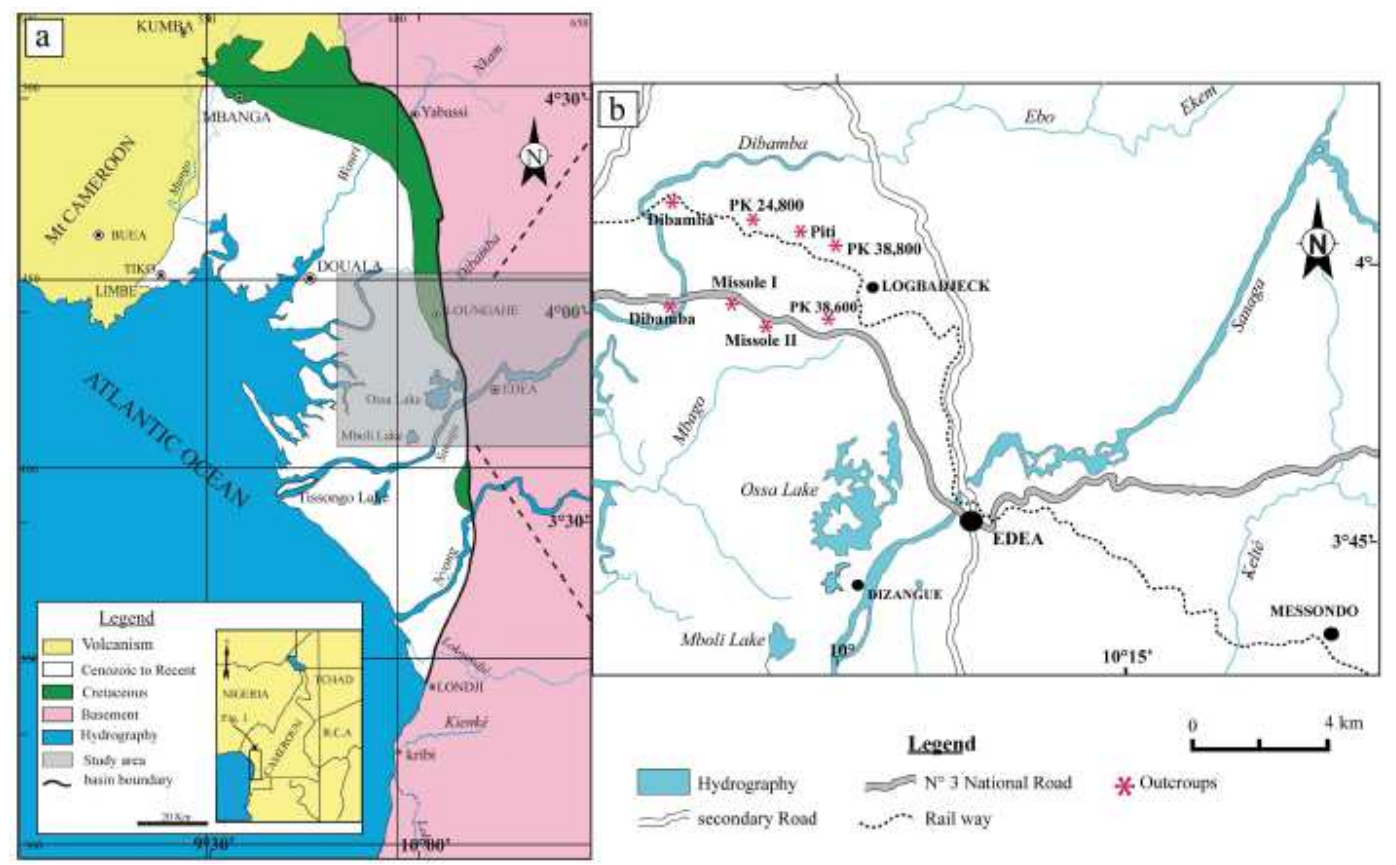

Fig. 1a. Location of Douala Basin in the Gulf of Guinea (after Njike Ngaha, 2005); (b) Magnification of study area shown in (a) with localization of outcrops

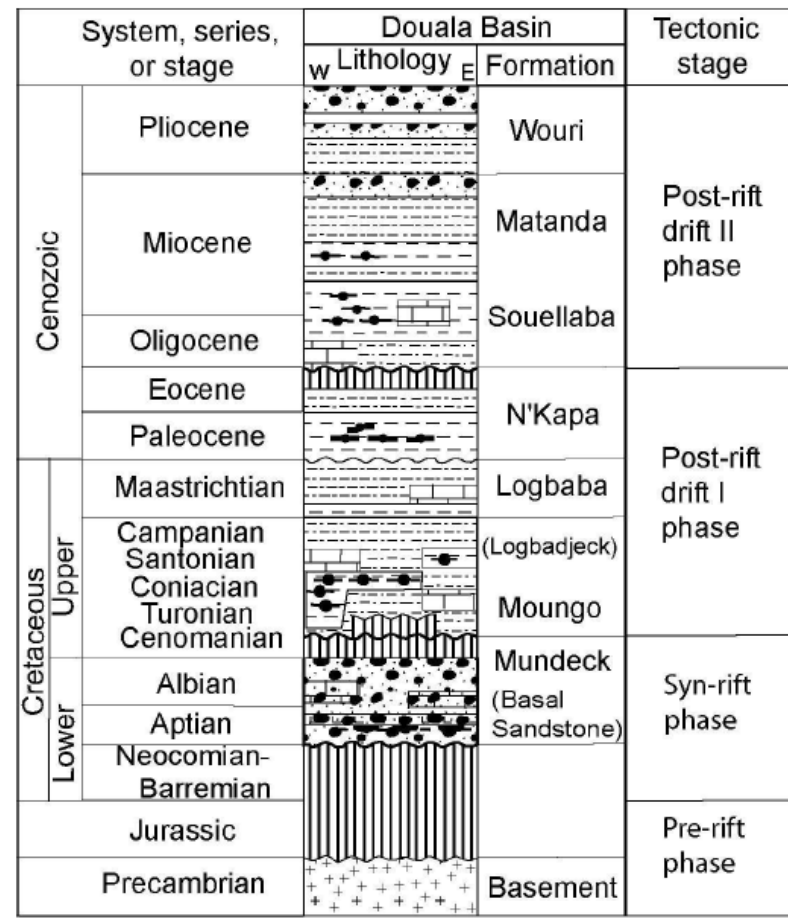

Legend

\begin{tabular}{ll} 
& Sandstone \\
& Siltstone \\
& Shale \\
& Potential source rock \\
& Simestone \\
\hline & Snconformity
\end{tabular}

Fig. 2. Tectono-lithostraphy of Douala Basin (adapted from Regnoult, 1986; Nguene et al., 1992; Manga, 2008) 
These sediments consists of coarse-grained sands interbedded with plastic clays belong to the Wouri formation indicate by Nguene et al. (1992).

\section{BASIC DATA AND METHODS}

The studied outcrops are located in the E-W central part of the Douala Basin, along the Yaoundé-Douala No 3 National Highway and the Yaoundé-Douala railway (Fig. 1b). These outcrops were investigated for about $20 \mathrm{~km}$ moving towards Douala. Outcrops described have been identified in the localities of Missolé II, Piti, Missolé I and Dibamba (Fig. 1b). About $300 \mathrm{~m}$ of sedimentary deposits have been described and analyzed on the basis of lithology, grain size and sedimentary structures. The facies description, their interpretation and their stratigraphic evolution were carried out. The facies codes used were modified according to (Miall, 1978; 1985; 1996; Mclean and Jerzykiewicz, 1978; Postma, 1990; Walker and Plint, 1992; Allen, 1996; Reading and Collinson, 1996).

\section{FACIES AND FACIES ASSOCIATIONS}

In this study, seventeen facies were identified and a summary of each facies description is given in Table $\mathbf{1 .}$ These facies were grouped into three major facies associations and will be described and interpreted below. The detailed facies $\log s$ are provided in Fig. 4.

\subsection{Facies Association A: Gravelly-Dominated}

This facies association consists of the four lithofacies (Gms, Gmg, Ghi and Gt) as described below.

\subsubsection{Description}

The Gms facies is a heterolithic conglomerate with a sandstone-clay matrix. The lithic elements of this conglomerate are $4-5 \mathrm{~cm}$ in diameter. These elements are rounded to subangular with quartz fragments being dominant. The unconsolidated matrix consists of coarse to medium-grained sandstones which is poorly sorted, mixed with clay and varies from grey to red, depending on the clay content (Fig. 3a). There is no graded bedding or other sedimentary structures and the bed varies from 1-12 $\mathrm{m}$ in thickness. The Gmg facies with $5 \mathrm{~m}$ thick is constituted by $\mathrm{cm}$-scale rounded to subangular quartz grains (Fig. 3b). It is associated locally to Ghi facies. The matrix consists of medium to coarse-grained sands. It presents graded bedding and its basal surface is erosive. The Ghi facies is coarsegrained sandstones with quartz pebbles $3-4 \mathrm{~cm}$ in diameter in a clayey sandstone matrix (Fig. 3c). At the basal boundary of this facies, rounded quartz pebbles are slightly imbricated. This coarse-grained sandstone is poorly sorted and rests on an erosive surface. The bed has thickness of about 4-6 m. The Gt facies is ferruginous coarse-grained sandstone, with rounded quartz pebbles $4-5 \mathrm{~cm}$ in diameter (Fig. 3d and $\mathbf{e})$. These pebbles occur in a sandstone matrix poorly sorted and are associated to $\mathrm{Sg}$ facies. In some places, Gt facies shows cross bedding rarely multistorey with pebbles lag at set base. The set has lowangle and oriented generally westward.

\subsubsection{Interpretation}

The Gms facies records deposition by debris flows, accompanied with sliding by gravity (Nilsen, 1982) on a slope. The predominance of the matrix composed of coarse to medium poorly sorted sands, mixed with clay indicates that the flow remained highly concentrated during transport and that the clasts remained closely packed during deposition (Fisher, 1971). This process was followed by a pseudoplastic grain flow (Nemec and Steel, 1984) that allowed facies Gmg to be put in place by gravity. Ghi facies shows a combination of characteristics that is usually associated with debris-flow deposits (poor sorting, erosive base) as well as features of stream-flow deposits (e.g., clast subrounding and clast imbrications). This facies is attributed to streamflow process resulting from a sediment transport by traction (Nilsen, 1982). This process was generated due to gravity by very high-energy water current on a moderate shelf slope (Nemec and Steel, 1984; Miall, 1996). The process was followed by mass-flow from turbulent currents. The cross-bedded ferruginous coarse-grained sandstones with rounded quartz pebbles (facies Gt), suggests relatively rapid sedimentation from a high-energy flow. The characteristics of these facies are consistent with deposition in fluvial channels from high-velocity flow in the deepest part of the stream (Allen, 1980; Miall, 1996; Collinson, 1996) or gravity flow produced by density-current (Gugliotta et al., 2013). The Gt facies is also interpreted to have been deposited as a channel lag under conditions of lower flow regime, with sediment transport occurring via tractional currents (Ghazi and Mountney, 2009). 
Bachirou Mfayakouo Chavom et al. / American Journal of Geosciences 4 (1): 8-23, 2014

Table 1. Summary of facies description from Missolé II, Piti, Missolé I and Dibamba localities in the central part of Douala Basin

\begin{tabular}{|c|c|c|c|c|c|}
\hline Facies & Description & Sedimentary structures & Bedding & Fossil content & $\begin{array}{l}\text { Depositional process } \\
\text { and interpretation }\end{array}$ \\
\hline Gms & $\begin{array}{l}\text { Rounded to subangular clast with } 4-5 \mathrm{~cm} \text { in } \\
\text { sized Heterolithic conglomerate with a } \\
\text { sandstone-clay matrix, poorly sorted }\end{array}$ & $\begin{array}{l}\text { Erosive basal boundary } \\
\text { ungraded }\end{array}$ & $\begin{array}{l}\text { Beds: } 1-12 \mathrm{M} \text { thick, } \\
\text { Dip: } 8-11^{\circ}, \text { Laterally } \\
\text { continuous }\end{array}$ & None & $\begin{array}{l}\text { Debris flows, accompanied } \\
\text { with sliding by gravity on a } \\
\text { slope at the edge of the rift basin }\end{array}$ \\
\hline Gmg & $\begin{array}{l}\text { Graded bedding conglomerate with } \mathrm{cm} \text {-scale } \\
\text { rounded to subangular quartz elements, matrix } \\
\text { consists of coarse to medium-grained sand }\end{array}$ & Erosive basal boundary, & $\begin{array}{l}\text { Beds: } 8 \mathrm{M} \text { thick, } \\
\text { Dip: } 10^{\circ} \text {, Laterally } \\
\text { continuous }\end{array}$ & None & Pseudoplastic grain flow process \\
\hline Ghi & $\begin{array}{l}\text { Poorly sorted coarse-grained sandstone with } \\
\text { quartz pebbles } 3-4 \mathrm{~cm} \text { in diameter slightly } \\
\text { imbricated and clayey sandstone matrix }\end{array}$ & $\begin{array}{l}\text { Imbrications, slightly } \\
\text { Erosive basal boundary }\end{array}$ & $\begin{array}{l}\text { Beds: } 4-8 \mathrm{M} \text { thick } \\
\text { tabular bed }\end{array}$ & None & $\begin{array}{l}\text { Stream flow process and sediment } \\
\text { transport by traction this process } \\
\text { was generated due to gravity by } \\
\text { very high energy water current } \\
\text { on a moderate shelf slope }\end{array}$ \\
\hline Gt & $\begin{array}{l}\text { Stratified gravely sandstone with rounded } \\
\text { quartz pebbles } 4-5 \mathrm{~cm} \text { in diameter, pebbles } \\
\text { occur in a sandstone matrix }\end{array}$ & $\begin{array}{l}\text { Trough cross-bedded sets, } \\
\text { rarely multistory; pebbles } \\
\text { lags at set base }\end{array}$ & $\begin{array}{l}\text { Beds: Dm-thick } \\
\text { lenticular bed }\end{array}$ & None & $\begin{array}{l}\text { Channelized lag deposit; high to lower } \\
\text { flow regime or gravity flow process } \\
\text { produced by density currents }\end{array}$ \\
\hline $\mathrm{Sm}$ & $\begin{array}{l}\text { Homogeneous coarse to me dium-grained } \\
\text { sand-stone, with mm-size elements } \\
\text { consisting of angular Immature grains } \\
\text { mainly quartz and feldspar }\end{array}$ & Massive & $\begin{array}{l}\text { Beds: Bar of several } \\
\text { meters thick }\end{array}$ & None & $\begin{array}{l}\text { Sand deposit coming directly from a } \\
\text { turbulent suspension of high } \\
\text { concentration mass flow or high } \\
\text { density subaqueous turbidity current }\end{array}$ \\
\hline $\mathrm{Sg}$ & $\begin{array}{l}\text { Medium and coarse-grained sandstones } \\
\text { with a clay matrix, mm-scale grains are } \\
\text { made up of angular to subangular quartz, } \\
\text { poorly to well sorted }\end{array}$ & $\begin{array}{l}\text { Normal graded, Erosive } \\
\text { basal boundary, angular } \\
\text { cross- stratification, } \\
\text { loads casts }\end{array}$ & $\begin{array}{l}\text { Beds: Bar of several } \\
\text { meters thick }\end{array}$ & None & $\begin{array}{l}\text { Decelerating mass flow deposit, } \\
\text { from a turbulent currents }\end{array}$ \\
\hline Sh & $\begin{array}{l}\text { Silty sandstone with medium to } \\
\text { fine-grained subrounded to rounded }\end{array}$ & $\begin{array}{l}\text { Horizontal lamination } \\
\text { meters thick }\end{array}$ & Beds: Bar of several & None & $\begin{array}{l}\text { Planar bedded deposits coming } \\
\text { from river flood periods with a high } \\
\text { flow regime }\end{array}$ \\
\hline St & $\begin{array}{l}\text { Fine to medium-grained sand subrounded } \\
\text { to rounded moderately to well sorted }\end{array}$ & $\begin{array}{l}\text { Low-angle cross- } \\
\text { stratification,slightly } \\
\text { erosive basal boundary }\end{array}$ & $\begin{array}{l}\text { Beds: Several meters } \\
\text { tabular bed }\end{array}$ & None & $\begin{array}{l}\text { Lower flow regime, low-relief } \\
\text { bed form or 3-D megaripples }\end{array}$ \\
\hline $\mathrm{Sc}$ & $\begin{array}{l}\text { Convoluted medium to fine-grained } \\
\text { sandstones, moderately sorted }\end{array}$ & Convoluted structure & $\begin{array}{l}\text { Beds: } 0.5-1 \mathrm{M} \text { thick } \\
\text { tabular bed }\end{array}$ & None & $\begin{array}{l}\text { Sediment liquefaction initiated } \\
\text { by excess waters pressure }\end{array}$ \\
\hline Ss & $\begin{array}{l}\text { Cross-stratified medium to fine-grained } \\
\text { sand well sorted with traces of bioturbation }\end{array}$ & Cross-stratification & $\begin{array}{l}\text { Beds: Several meters } \\
\text { thick, tabular bed }\end{array}$ & $\begin{array}{l}\text { Fragments of } \\
\text { bivalves shells, } \\
\text { bioturbation }\end{array}$ & $\begin{array}{l}\text { Shoreface deposits with an interaction } \\
\text { of wave and storms }\end{array}$ \\
\hline Fl & $\begin{array}{l}\text { Clayey silstone with few fragment of lignit } \\
\text { bioturbation and plant root are common }\end{array}$ & $\begin{array}{l}\text { Horizontal lamination, } \\
\text { flute marks }\end{array}$ & $\begin{array}{l}\text { Beds: } \mathrm{Cm} \text { to several } \\
\text { meters thick }\end{array}$ & $\begin{array}{l}\text { Fragment of } \\
\text { lignite plant root, } \\
\text { bioturbation }\end{array}$ & $\begin{array}{l}\text { Deposition from suspension and from } \\
\text { from weak traction currents }\end{array}$ \\
\hline $\mathrm{Fr}$ & $\begin{array}{l}\text { Grey argillaceous spotted with purple, } \\
\text { bioturbations are frequent }\end{array}$ & Massive & $\begin{array}{l}\text { Beds: } 2 \mathrm{~m} \text { thick } \\
\text { Dip: } 8-11^{\circ} \text {, laterally } \\
\text { continuous }\end{array}$ & Bioturbation & $\begin{array}{l}\text { Levee or overbank deposits formed } \\
\text { during floods }\end{array}$ \\
\hline Fm & $\begin{array}{l}\text { Massive multicoloured kaolinic clays with } \\
\text { mud-crack, bioturbation, microorganism } \\
\text { activity and plant root traces are common }\end{array}$ & Massive, mud-cracks & $\begin{array}{l}\text { Beds: Several meters } \\
\text { thick, tabular bed }\end{array}$ & Bioturbation, & $\begin{array}{l}\text { Deposition by suspended fine particles } \\
\text { animal and plant root traces }\end{array}$ \\
\hline Fsf & $\begin{array}{l}\text { Grey to black clays rich in fossils, } \\
\text { containing sandy clay and some coal debris, } \\
0.9 \% \text { total organic carbon content }\end{array}$ & Massive & $\begin{array}{l}\text { Beds: Several meters } \\
\text { thick, tabular bed }\end{array}$ & $\begin{array}{l}\text { Coal debris, } \\
\text { moulds of } \\
\text { bivalves and } \\
\text { gasteropods } \\
\text { shells }\end{array}$ & $\begin{array}{l}\text { Deposits from suspension and } \\
\text { a relatively anoxic confined } \\
\text { or closed environment }\end{array}$ \\
\hline Fml & $\begin{array}{l}\text { Compacted, fissile black shale with isolate } \\
\mathrm{d} \text { layers of silt and many animal fossils, } \\
\text { containing an average total organic matter } \\
\text { content of } 1.15 \%\end{array}$ & Thin-laminated & $\begin{array}{l}\text { Beds: Several meters } \\
\text { thick, tabular bed }\end{array}$ & $\begin{array}{l}\text { Moulds of } \\
\text { bivalves and } \\
\text { gasteropods } \\
\text { shells, } \\
\text { Nautilus debris }\end{array}$ & $\begin{array}{l}\text { Deposits from suspension setting, far } \\
\text { away from wave action }\end{array}$ \\
\hline Fmlc & $\begin{array}{l}\text { Black clays with carbonaceous plant debris, } \\
\text { or thin-laminated containing organic materials } \\
\text { with an average organic content of } 0.68 \%\end{array}$ & $\begin{array}{l}\text { massive or } \\
\text { hin-laminated }\end{array}$ & $\begin{array}{l}\text { Beds: } 35-40 \mathrm{M} \text { thick } \\
\text { Dip: } 11^{\circ} \text {, Laterally } \\
\text { continuous }\end{array}$ & $\begin{array}{l}\text { Carbonaceous } \\
\text { plant debris } \\
\text { moulds of } \\
\text { bivalves shells }\end{array}$ & $\begin{array}{l}\text { Deposits from suspension setting in calm } \\
\text { marine environment }\end{array}$ \\
\hline $\mathrm{Fc}$ & $\begin{array}{l}\text { Fossiliferous limestone with numerous } \\
\text { fragments of bivalves and gasteropods, } \\
\text { also has subronded to rounded quartz pebbles }\end{array}$ & Massive & $\begin{array}{l}\text { Beds: } 65-\mathrm{Cm} \text { thick } \\
\text { lenticular bed }\end{array}$ & $\begin{array}{l}\text { Fragment of } \\
\text { bivalves and } \\
\text { gasteropods }\end{array}$ & Wave-influenced environment \\
\hline
\end{tabular}



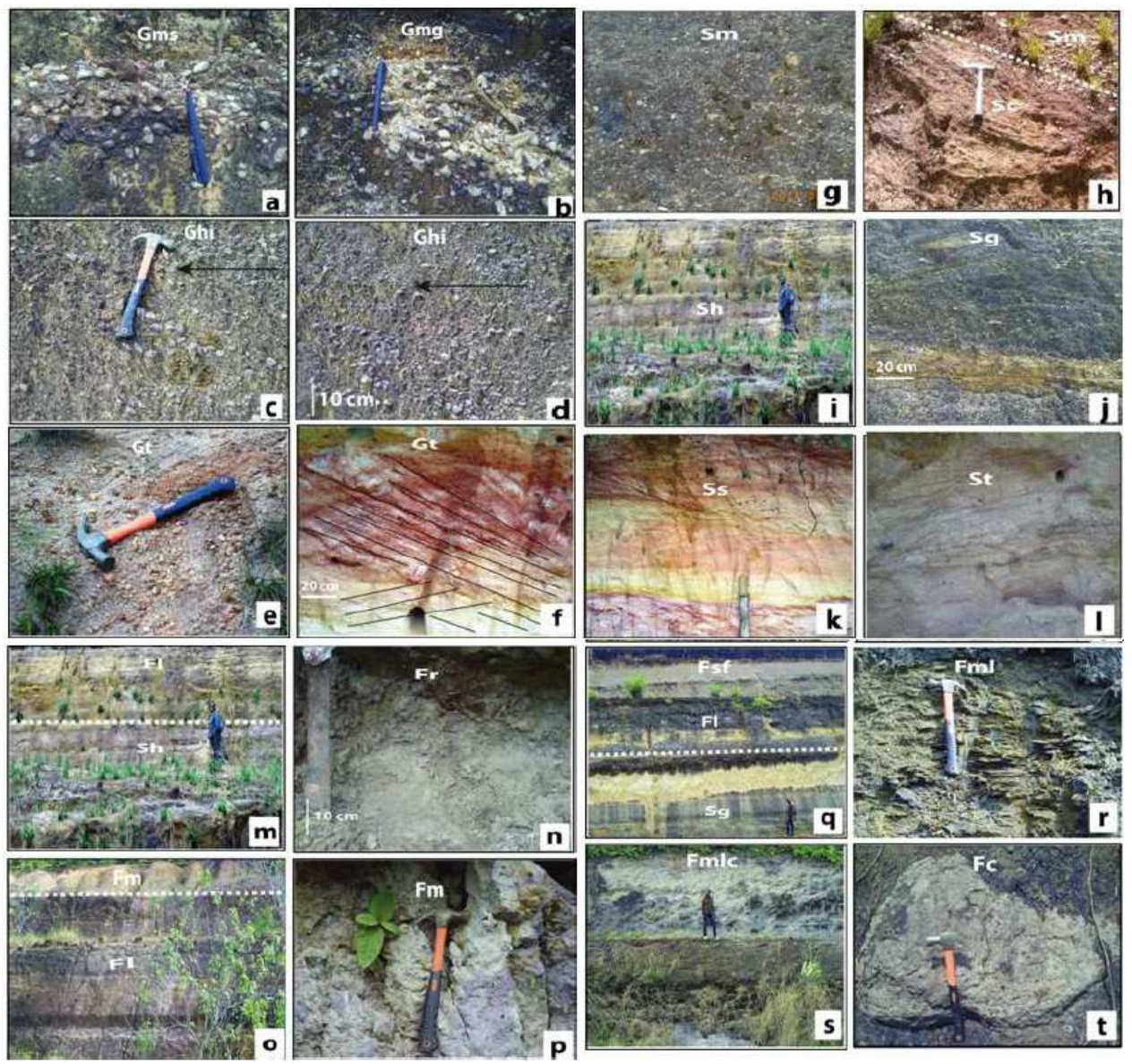

Fig. 3. Conglomeratic, sandstone, siltstone, clay/shale and limestone facies cropping out in the East-West central part of Douala Basin along localities of Missolé II, Piti, Missolé I and Dibamba. (a) Gms facies (conglomerate sandstones with clay matrix without sedimentary structures). (b) Gmg facies (conglomerate with sandstone matrix "clast supported". (c and d) Ghi facies (coarse sandstone with imbricated elements noted the preferential orientation of quartz pebbles following their major axis). (e and f) Gt facies (crossbedding coarse sandstone). (g) Sm facies (coarse to medium-grained sandstones). (h) Sc facies (fine-grained sandstone with convoluted structures, associated to Sm facies). (i) Sh facies (fine to medium-grained sandstone showing horizontal lamination). (j) Sg facies (fine to mediumgrained sandstone). (k) Ss facies (fine to medium-grained cross-stratified sandstones). (l) St facies (medium to finegrained cross-bedded sandstones). (m) Vertical succession of Sh an Fl facies. (n) Fr facies (grey clays bioturbed, with massive structure). (o) Vertical succession of Fl and Fm facies. p) Fm (kaolinic spotted clays). (q) Fsf facies (grey to black clays, associated to Fl and Sg facies). (r) facies Fml (black laminated shale). (s) Fmlc facies (grey to black clays with some carbonaceous debris). ( $\mathrm{t}$ ) Fc facies (limestones very rich in animal debris)

\subsection{Facies Association B: Sandy-Dominated}

This facies association is composed of fine to medium and coarse-grained sandstones containing sometimes pebbles. It consist of six lithofacies includes the cross-bedded Sandstone (St), the coarse to mediumgrained sandstone $(\mathrm{Sm})$, the horizontally bedded Sandstone (Sh), fine to medium-grained Sandstone
$(\mathrm{Sg})$, medium to coarse-grained cross-stratified sandstone (Ss) and the convoluted Sandstone (Sc).

\subsubsection{Description}

The Sm facies is a homogeneous coarse to mediumgrained sandstones organized in bars of several meters. The grains are mostly mm-size consisting of angular immature mainly quartz and feldspar grains (Fig. 3f). 
Some rock fragments of gravel size are also present. This facies has ferruginous cement and associated with convoluted Sandstone facies (Sc), coarse-grained sandstone Ghi). The $\mathrm{Sg}$ facies is organized in bars of several meters. It is made up of fine to medium and coarse-grained sandstones with a clay matrix, exhibiting traces of oxidation (Fig. 3g). The mm-scale grains are made up of angular to subangular quartz, with some feldspar. This facies is fairly homogeneous and poorly to well sorted and associated with horizontally bedded sandstone (Sh), cross bedded ferruginous coarse-Grained sandstone (Gt). It is showing in some place giant load casts at its basal boundary which is a simple local deformation. The St facies is composed of fine-grained sands coarsening-upward with thickness of about several meters. It consists of medium to coarse-grained, moderately to poorly sorted (Fig. 3h). Weathered surfaces show rubefaction trace, whereas fresh surfaces are white or light-pink. The coarse-grained sands have clays as its matrix. Grains are subangular to subrounded and in places the sands contains coarse-grained sandstones intraclasts formed from reworked sediments. This facies presents basal cross-stratification, which mostly form small scale troughs with low-angle. It is associated with kaolinic clay Facies (Fm), black clay Facies (Fmlc) and carbonate Facies (Fc). The Sh facies occurs in bars of several meters thickness, formed by medium to finegrained sandstones (Fig. 3i). This facies shows a distinct horizontal lamination. It is associated with clayey siltstone Facies (Fl). The Ss facies is sorted medium to fine-grained sands occurring in a clay matrix with yellowish spots in some areas, which indicated a sign of rubefaction. This facies exhibit a distinct cross-stratification and some fragments of bivalve shells and traces of bioturbation (Fig. 3j). This facies generally has a thickness of several meters. The Sc facies is characterized by convoluted medium to fine-grained sandstones moderately sorted with thickness of about $0.5-1 \mathrm{~m}$. This facies is associated with Sm facies (Fig. 3k).

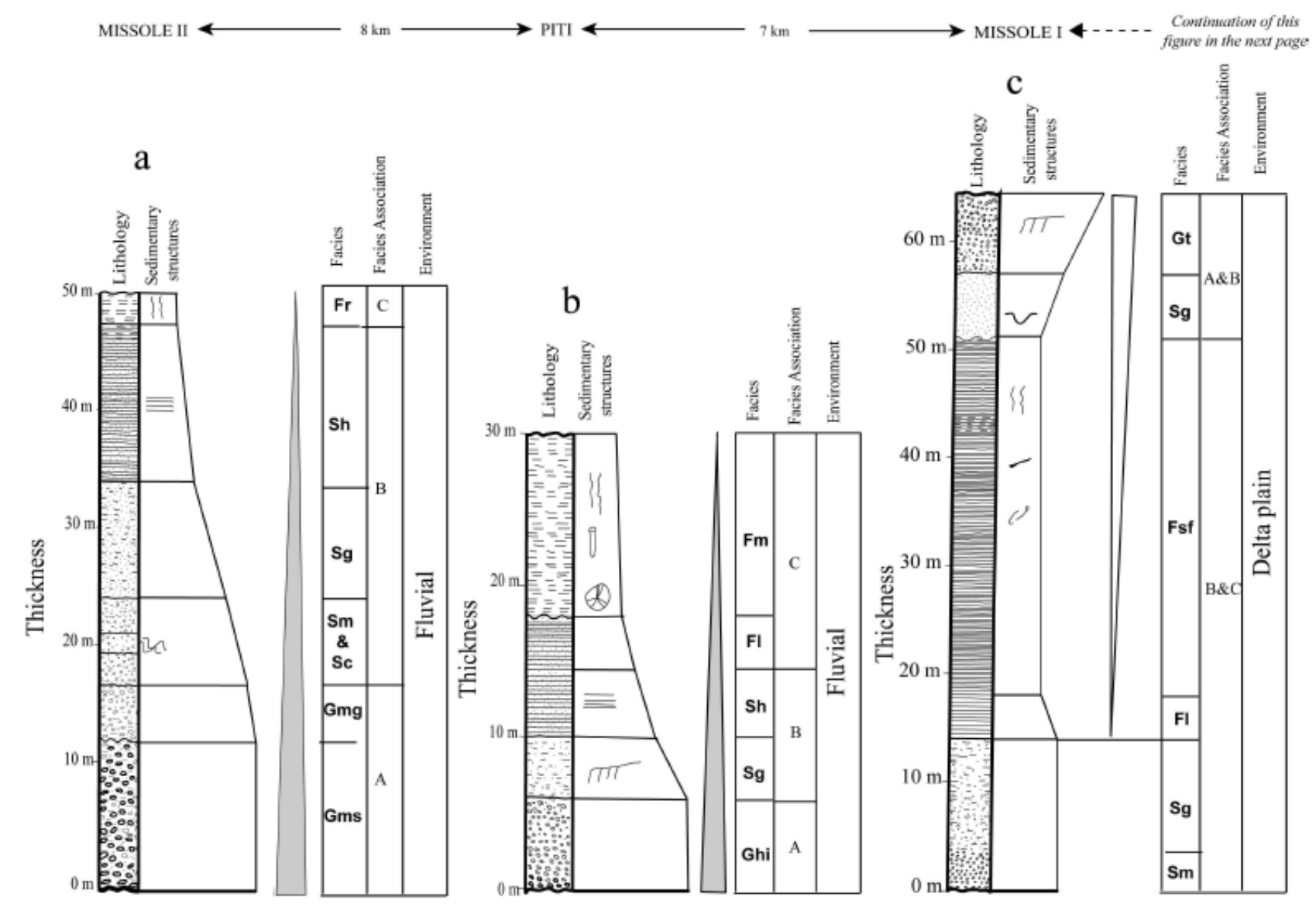

Fig. 4. Detailed facies logs of formations cropping out in the Missolé II and I, Piti and Dibamba localities 
Bachirou Mfayakouo Chavom et al. / American Journal of Geosciences 4 (1): 8-23, 2014

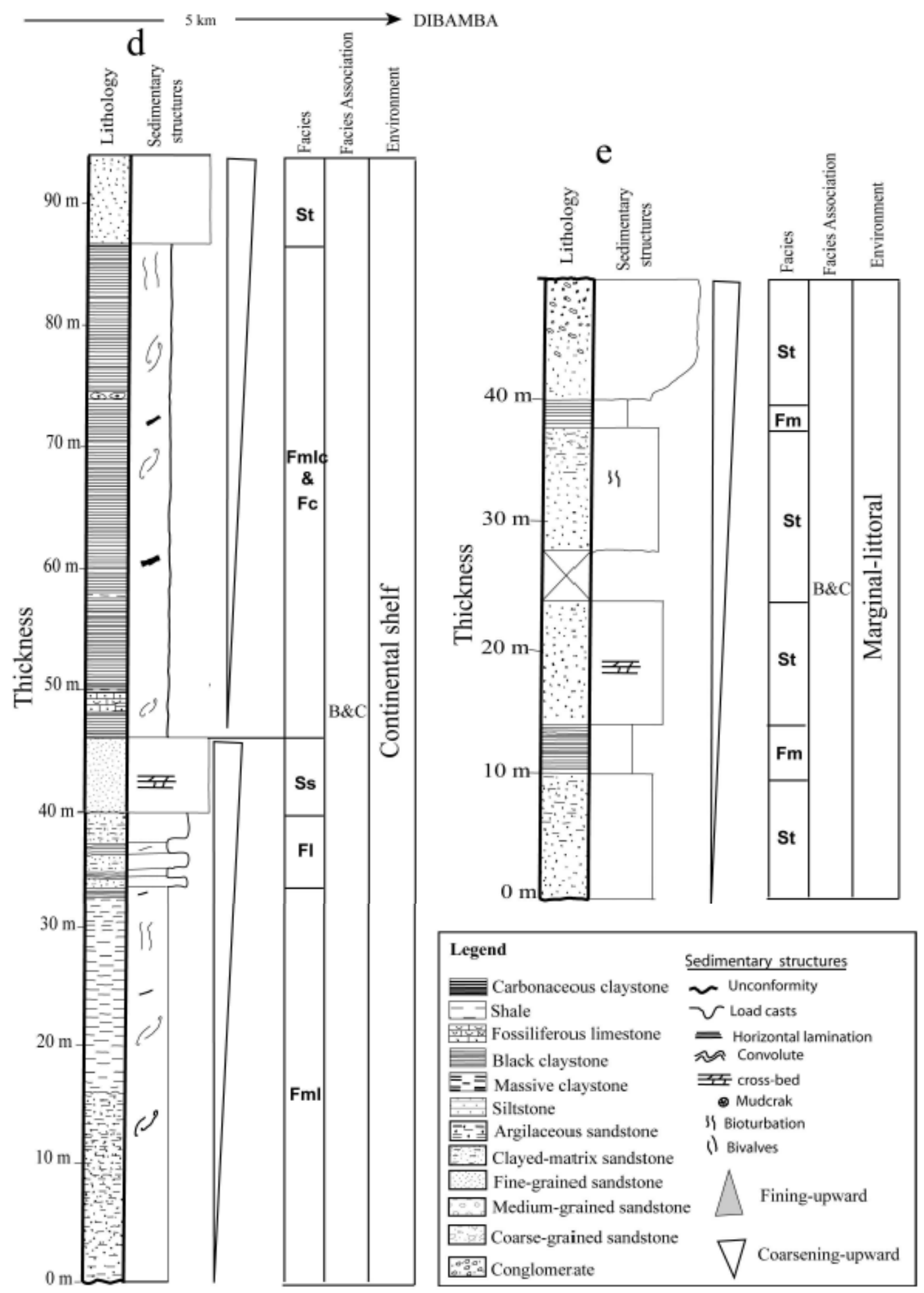

Fig. 4. Continued 


\subsubsection{Interpretation}

The Sm facies is interpreted as a sand deposit coming directly from a turbulent suspension of hyperconcentred mass flow or a high-density subaqueous turbidity current (Ghibaudo, 1992). The convoluted fine-grained Sandstone (Sc) probably results from sediment liquefaction initiated by excess pure waters pressure suggested by Cojan and Thiry (1992). The Sg facies is interpreted as mass flow deposits from turbulent suspension. Deceleration of these turbulent suspensions would have produced most of the deposits of the $\mathrm{Sg}$ facies (Lowe, 1982). The loads casts observed at the basal boundary of this facies probably generated by pressure balance within sediment with interface sand/clay deformations. The moderate to poor sediment sorting, the low-angle of trough cross-stratification favours a fluvial bedform interpretation of St facies (Collinson, 1996; Miall, 1996; Eriksson et al., 1998). This deposit may be the result of migration of 3-D megaripples responding to changes in the speed and direction of currents (Chamley, 1999). This facies may also have been deposited during successive filling phases of channels or during progradation of meandering bars (Cojan and Renard, 2006). The Sh facies is interpreted as plane bed sand of upper flow regime deposited in section of river valley as channel fill developed on top of sand bars (Miall, 1978; Harms et al., 1995). The Ss facies is interpreted as deposit by oscillatory flow in storm dominated shoreface environment (Allen, 1996).

\subsection{Facies association $\mathrm{C}$ : Fine grain dominated}

The fine grain dominated facies association is composed of seven lithofacies; the clayey siltstone Facies (Fl), the grey argillaceous Facies (Fr), the kaolinic clay Facies (Fm), black clay Facies (Fsf), the shale/mudstone (Fml), the massive or laminated claystone (Fmlc) and carbonaceous Facies (Fc).

\subsubsection{Description}

The Fl facies forms clayey siltstone and occurs in the form of an individual bar with a thickness of several meters and associated with horizontally bedded Sandstone facies (Sh), kaolinic claystone (Fm) and shale/mudstone Facies (Fml). It shows parallel laminations and weathered surfaces show traces of rubefaction, whereas fresh surfaces are white or lightpink. A few fragments of lignite were observed, bioturbation and plant root traces are common (Fig. 31). This facies presented on the top rounded-sharp flute marks (Fig. 3m). The grey argillaceous Facies (Fr) with $2 \mathrm{~m}$ thick has massive structure and grey spotted with purple. Traces of bioturbation are frequently observed in this facies (Fig. 3n and o). It is associated with horizontally bedded Sandstone (Sh). The multicoloured kaolinic clays Facies (Fm) has a thickness of several meters and associated with clayey siltstone (Fl), trough cross bedded Sandstone ( $\mathrm{St}$ ). This facies is massive and shows locally desiccation-cracks (Fig. 3p). Bioturbation, microorganism activity and plant root traces are also common (Fig. 3q). The black clay Facies (Fsf) is massive claystone with fossils content as moulds of bivalves and gastropod shells. There is also the presence of some coal debris. This facies is associated with clayey siltstone Facies (Fl) and fine to medium-grained Sandstone facies ( $\mathrm{Sg})$. The individual bed has thickness of about $15 \mathrm{~m}$ (Fig. 3r and s). The Fml facies consists of compacted, fissile black shale (Fig. 3t). These clays may be bioturbated in some areas. Many animal fossils are observed including shell moulds of molluscs (bivalves, gastropods), as well as Nautilus debris. Its thickness is estimated at more than ten meters. Towards the top of the bed, this facies is associated with clayey siltstone Facies (Fl). The massive or laminated black claystone Facies (Fmlc) shares the same features as Fml facies but contains some carbonaceous plant debris (Fig. 3u). It is associated with medium to coarse-grained Sandstone facies $(\mathrm{Sm})$ and limestone Facies $(\mathrm{Fc})$. The individual bed is about $40 \mathrm{~m}$ thick and presents at the top, some ferruginous nodules parallel to the stratification. The presence of parallel laminations is also noted at the bottom of the bed. The limestone Facies (Fc) occurs as a lenticular bed with thickness of about $0,65 \mathrm{~m}$ thick. It is associated with Fmlc facies and in addition to numerous fragments of bivalves and gastropods; it also has siliciclastic elements such as subrounded to rounded quartz pebbles which sometimes show a ferruginous coating (Fig. 3v).

\subsubsection{Interpretation}

The Fl facies is interpreted as deposition from suspension settling and from weak traction currents during flood events commonly observed during overbank sedimentation on the floodplain. Similar facies were interpreted as deposition in shallow water over washing or represent the deposits of waning stage flood deposition, chiefly in overbank areas with the majority of deposition occurring from suspension settling and with only limited bedload transport via weak currents (Walker and Cant, 1984; Reading, 2009; Hjellbakk, 1997; Chamley, 1999). Miall (1978) interpreted the Fr facies as a levee or overbank deposit formed during flood events. The Fm facies is interpreted as representing deposition by suspended fine particles during overflow periods. Similar facies is interpreted as overbank or drape deposits, thus it may represent the most distal floodplain (Miall, 1978; 1985). 
The presence of desiccation cracks in this facies is also typical of most of floodplain deposits in a semi-arid and arid climate (Turner, 1980; Bridge, 2006; Cain and Mountney, 2009). The Fsf facies is interpreted as suspension deposit settling from weak currents or shallow lacustrine deposit (Miall, 1996; Nichols, 2013). The dark colour of this facies may suggest a relatively anoxic confined or closed environment, which can favoured the preservation of organic matter. The Fml facies result from suspension settling in a calm environment. Similar facies is interpreted as suspension settling deposit far away from wave action in a marine environment (Reading and Collinson, 1996). The Fmlc facies is interpreted as suspension settling deposit in a calm marine environment with a large portion of marine water (Johnson and Baldwin, 1996). The limestone facies $\mathrm{Fc}$ represent accumulation in a carbonate-rich shallow marine environment subjected to sediment input from the neighbouring terrestrial environment (Wakefield and Mountney, 2013).

\section{FACIES SUCCESSIONS}

According to (Dalrymple, 2010), vertical facies successions represent genetically related lithofacies that occur in combination and typically represent individual depositional environments. Five types of facies successions are identified from the description and associations of facies of the formations cropping out in the E-W central part of the Douala Basin: Braided river, meandered river, delta plain, continental shelf and marginal-littoral facies succession.

\subsection{Braided River Facies Succession}

This facies succession consists at the bottom of the gravelly dominated facies association, Gms and Gmg facies with a thickness of about $16-18 \mathrm{~m}$. This facies is poorly sorted with outsized clast and without sedimentary structures. This suggests that deposition of this facies was controlled by debris flow process accompanied with sliding by gravity on a slope, mainly associated with a pseudoplastic grain flow (Nilsen, 1982; Nemec and Steel, 1984). The gravelly dominated facies association exhibit vertical and lateral evolution towards the sandy dominated facies Association ( $\mathrm{Sm}, \mathrm{Sg}, \mathrm{Sc}$ and $\mathrm{Sh}$ ) composed of coarse to medium-grained, medium to finegrained sandstones, horizontally sandstone and the argillaceous Facies (Fr) from the fine dominated facies association with thickness of about 30-32 m. This facies succession shows general fining-upward package (Fig. 4a). This suggests progressive decreasing of the flow process while argillaceous facies represent overbank or levee deposits. However it is inferred that convolute bedded sandstones are indication of sediment liquefaction initiated by excess pure water pressure (Cojan and Thiry, 1992).

\subsection{Meandering River Facies Succession}

This facies succession is made up at the bottom of gravelly dominated facies association (Ghi) composed of the pebbly very coarse-grained sandstones with thickness of about 4-6 $\mathrm{m}$. This facies is poorly sorted and pebbles clast are rounded and slightly imbricated. This suggests deposition by stream-flow process or transport by traction due to gravity on a moderate shelf slope (Nemec and Steel, 1984; Miall, 1996). The gravelly dominated facies association show vertical and lateral evolution towards the sandy dominated facies association ( $\mathrm{Sg}$ and $\mathrm{Sh}$ ) consists of medium to fine-grained sandstones and $\mathrm{Fl}$ and Fm facies from fine dominated facies association. This facies succession has overall thickness of about $30 \mathrm{~m}$ and show fining-upward package (Fig. 4b). The sandy dominated facies association is interpreted as meandering river channel deposits while the silts and mud facies represent floodplain deposits (overbank).

\subsection{Delta Plain Facies Succession}

This facies succession indicates at the bottom sandy dominated facies association $(\mathrm{Sm})$ consists of medium to fine-grained sandstones with clay matrix. This facies is interpreted as a sand deposit coming directly from a turbulent suspension of hyperconcentred mass flow or a high-density subaqueous turbidity current (Ghibaudo, 1992). The vertical evolution of this facies succession exhibits coarsening-upward motif (45-50 $\mathrm{m}$ thick) composed of fine dominated facies association, $\mathrm{Fl}$ and Fsf facies and finally fine to medium Sandstone $(\mathrm{Sg})$ from sandy dominated facies association and cross bedded coarse-Grained sandstone (Gt) from gravelly dominated facies association. The Fl and Fsf facies are interpreted as suspension settling deposits in a calm and confined or closed environment which could be a brackish environment that characterizes a pro-delta (Mutti et al., 2000) or a tidal deposits of a flooding continental margin, observed in estuarine environments (Shanmugam et al., 2000). The Sg facies is interpreted as mass flow deposits from turbulent suspension while the Gt facies suggest relatively rapid sedimentation from a high-energy flow. The characteristics of these facies are consistent with deposition in fluvial channels from high-velocity flow in the deepest part of the stream (Allen, 1980; Miall, 1996; Collinson, 1996) or gravity flow produced by density-current (Gugliotta et al., 2013). This facies succession is interpreted to represent shallow marine to delta plain depositional system based on its coarsening-upward nature (Fig. 4c). 


\subsection{Continental Shelf Facies Succession}

This succession is made up of fine grain dominated facies association (Fl, Flm, Flmc and Fc) composed of silt, compacted, fissile black shale, massive or laminated black claystone, limestone and medium to coarse-grained sandstones from sandy dominated facies association. This succession exhibits coarsening-upward motif with thickness of about $100 \mathrm{~m}$. The depositional processes indicate by sandstone facies characterized by the presence of shells fragments of bivalve, cross stratification and bioturbation, provide evidence of storm currents and deposit by oscillatory flow in storm dominated shoreface environment reported for similar facies by Allen (1996); Hamberg and Nilsen (2000). The fine grain dominated facies association is interpreted as suspension settling deposits in a shallow marine depositional environment. However, fluctuation of sea level and thermal subsidence have favoured deposition of thick black clays bed with a level of ferruginous nodules which indicates period of oxidizing of depositional environment. The coarseningupward nature of this facies succession is interpreted to repres- ent storm-dominated continental shelf depositional system (Fig. 4d).

\subsection{Marginal-Littoral Facies Succession}

The succession is composed of sandy dominated facies association (St) consist of medium to coarse-grained cross bedded sandstones and the massive kaolinic clays Facies (Fm) from fine grain dominated facies association. The $\mathrm{St}$ facies is interpreted as fluvial bedform deposit outcome of migration of 3-D megaripples responding to changes in the speed and direction of currents (Chamley, 1999). The Fm facies is interpreted as floodplain deposit (overbank). The coarsening-upward packages of this facies succession can be interpreted as a result of sea level fall and resumption of fluvial activities (Fig. 4e). This is marked by an influx of greater clastic sediments resulting from erosion of the edges of the basin.

\section{FACIES SUCCESSION STRATIGRAPHIC EVOLUTION AND DEPOSITIONAL MODEL}

The studied outcrops exposed at the E-W central part of the Douala Basin comprise about $300 \mathrm{~m}$ thick of sediments consists of conglomerates, pebbly coarse, medium and fine-grained sandstones with siltstones, mudstone, shale and limestone. The five facies successions described herein are closely related and their inter-relationship supports their spatial and temporal evolution from fluvial to delta plain overlain progradationally by continental shelf and then marginallittoral deposits. The depositional model suggest for the formations cropping out at the Missole II, Piti, Missole I and Dibamba localities in the Douala Basin was developed from the lithofacies, lithofacies association studies and facies succession stratigraphic connection (Fig. 5). The model involves major depositional systems of fluvial to delta plain, continental shelf and marginal-littoral. The fluvial systems with braided and meandering channel are inferred to have fed delta plain, continental shelf and marginal-littoral system with sediment. The marine facies assemblage shows a large terrigenous influence.

\section{DISCUSSION}

The spatial and temporal evolution of the depositional environment of studied formations is proposed and was probably controlled by tectonics influencing transgressive and regressive movements of marine water as well as the sea levels change. In the Douala Basin as in the other basins of West African margin, the initial extension movement created a series of normal faults in the basement of the basin. The replay of these faults was created frequent subsidence movements in the basin. All of these have been at the base of the changes in the nature of the depositional environment. The facies analysis, facies association interpretation and vertical and lateral facies successions have permitted the generalized evolution of depositional patterns as progradational successions. Continental depositional processes of fluvial, marginal-littoral and delta plain and marine depositional processes of continental shelf were responsible for the deposition of formations of Missole II, Piti, Missole I and Dibamba localities in the central part of the Douala Basin. According to Robertson (1992), the equatorial portion of the South Atlantic continues to experience rapid extension during the Early Palaeocene and sedimentary basins in this surrounding area will undergo rapid subsidence. Cenozoic deposition in the Douala Basin started within this context with gravity driven and mud flow sedimentation in a fluvial environment with braided and meandering channel (Fig. 5a). Towards the basin axis, textural changes occur from very coarse-medium grained to fine-grained sandstone, siltstone and black claystone of the delta plain environment, due to a relative transgression of the sea in the Douala Basin. This marine transgression was demonstrated by Regnoult (1986) and would have attained its maximum in the Ypresian. However, the subsidence phase which has favoured the deposit of marine facies would have broken up during the late Eocene by an uplifting episode reported by (Nguene et al., 1992; Benkhelil et al., 2002; Dickson et al., 
2003). This uplift has contributed to a regression of the sea followed by erosion of a part of the emerged margin (Fig. 5b). This period of regression was evidenced by the presence of a small coarseningupward motif of the delta plain facies succession. This erosive period coincides with the relative global decline in sea level and has contributed to build a regional unconformity surface called "surface africaine I" reported by Reyre (1966) as well as in the Gabon, Dahomey and Ivory Coast basins and would have significantly contributed to the building of the current continental shelf. At the central part of the basin, fine to medium-grained sandstone, siltstone, shale, massive or laminated black claystone and limestone facies have been reported and formed the stormdominated continental shelf deposits. Deposition of these facies was made probably during the Oligocene to Early Miocene thermal subsidence of the Douala Basin, renewed after uplift and erosion episode of the emerged margin during the Late Eocene indicate by Nguene et al. (1992). In addition this thermal subsidence coincides with the relative sea level rise on the continental shelf completely builds in the Douala
Basin (Fig. 5c). This marine transgression was also carried out in the Kwanza and Congo Basins by Logar (1983); Reyre (1984), but has not yet been confirmed in the Gabon basin. During the Middle Miocene, the edification of the Cameroon Volcanic Line reported by (Nguene et al., 1992; Benkhelil et al., 2002) was probably responsible for the uplift of the margin of the basin and the regression of marine waters westward. Marginal-littoral environment was developed within this context and sedimentation was marked by a large influx of clastic sediments resulting from erosion of the edges of the basin (Fig. 5d).

However, despite a few manifestations of faulting subsidence observed at the bottom of the studied series through the presence of conglomerates and some soft sediment deformations, it is noted that any manifestation of the faulted subsidence has been identified in the upper part of the studied series. This allows agreeing upon the hypothesis of thermal subsidence which characterizes the Douala Basin during the Cenozoic suggested by Nguene et al. (1992) and seems to be accepted in almost all basins in the West African margin by Logar (1983; Reyre, 1984).

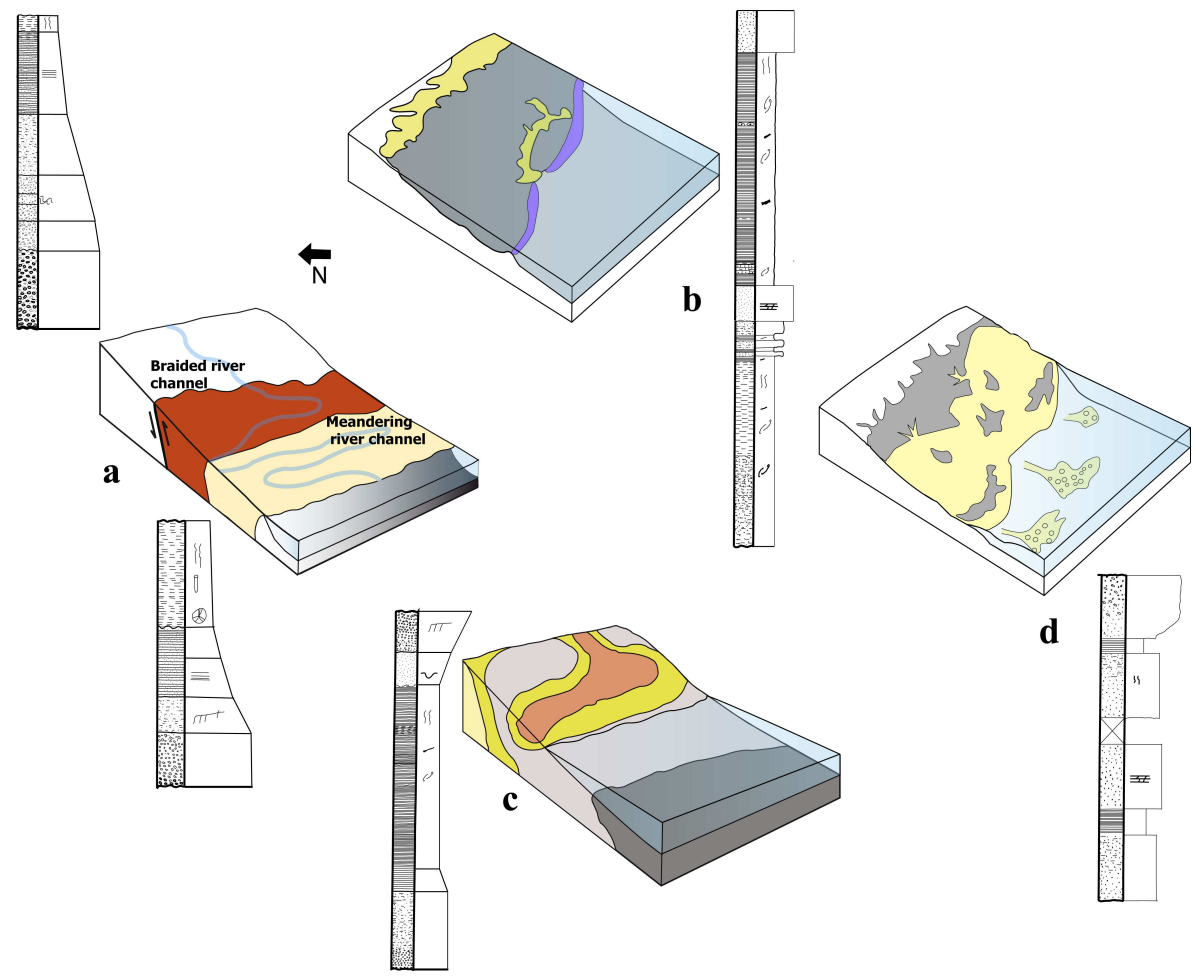

Fig. 5. Schematic view of depositional model of study formations cropping out in the E-W central part of Douala Basin. (a) Fluvial system depositional model. (b) Deltaic plain environment depositional model. (c) Continental shelf environment depositional model. (d) Marginal-littoral environment Depositional model 


\section{CONCLUSION}

Facies analysis of the Cenozoic formations cropping out at the E-W central part of the Douala Basin allows identification of depositional environments and made possible suggestion on the evolution of the depositional model for the successions. The five facies successions exhibit vertical and lateral facies evolution from braided and meandered channel of fluvial environment at the base to delta plain environment along the basin axis and the continental shelf to marginal-littoral environment at the central part of the basin. Debris flow processes dominated deposition of gravelly dominated facies associations, the poor sorting and subangularity of most of the coarse detritic clasts indicate source from nearby area. The proposed depositional model has evolved over time. This evolution was probably controlled by sag subsidence influencing transgressive and regressive movements of marine waters as well as the changes in sea level, climatic changes or combination of both in the Douala basin. This condition is similar to that for the most part of the other basins of West African margin.

\section{ACKNOWLEDGMENT}

This study benefited from the help of Prof. François BAUDIN from Paris VI University who strongly improved the early version of the manuscript. The authors also thank Dr Oliver Njoh for hid useful suggestions and for correcting the English language.

\section{REFERENCES}

Allen, G.P., 1996. Sedimentologiay estratigrafia de los yacimientos aluvialesy deltaicos. "Clastic facies course ». Queensland University of Technology.

Allen, J.R.L., 1980. Sand waves: A model of origin and internal structure. Sedimentary Geol., 26: 281-328. DOI: 10.1016/0037-0738(80)90022-6

Belmonte, Y.C., 1966. Stratigraphie du bassin sédimentaire du Cameroun. Proceeding of the 2nd West African Micropaleontologist Colloquium, (AMC' 66), Ibadan, Nigeria, pp: 7-23.

Benkhelil, J., P. Giresse, C. Poumot and G. Ngueutchoua, 2002. Lithostratigraphic, geophysical and morpho-tectonic studies of the South Cameroon shelf. Marine Petroleum Geol., 19: 499-517. DOI: $10.1016 / \mathrm{S} 0264-8172(02) 00002-8$
Bridge, J.S., 2006. Fluvial facies models: Recent developments. Soc. Econ. Pal. Min. Spec. Pub., 84: 85-170. DOI: $10.2110 /$ pec.06.84.0085

Cain, S.A. and N.P. Mountney, 2009. Spatial and temporal evolution of a terminal fluvial fan system: The Permian Organ Rock Formation, South-east Utah, USA. Sedimentology, 56: 1774-1800. DOI: $10.1111 /$ j.1365-3091.2009.01057.x

Chamley, H., 1999. Base de Sédimentologie. 1st Edn., Dunod, Paris, ISBN-10: 2100048848, pp: 178.

Cojan, I. and M. Thiry, 1992. Seismically induced deformation structures in Oligocene shallowmarine and aeolian coastal sands (Paris Basin). Tectonophysics, 206: 79-89. DOI: 10.1016/0040-1951(92)90369-H

Cojan, I. and M. Renard, 2006. Sédimentologie. Un bon Ouvrage Récent (en Français) de Sédimentologie Intégrant les Derniers Développements (Analyse Séquentielle, Diagenèse,). Pas Beaucoup de Photographies, Mais de Bons Schéma. 1st Edn., Dunod, Paris, ISBN-10: 210049623 9, pp: 444.

Coward, M.P., E.G. Purdy, A.C. Ries and D.G. Smith, 1999. The Distribution of Petroleum Reserves in Basins of the South Atlantic Margins. In: The oil and gas habitats of the South Atlantic. Cameron, N.R., R.H. Bate and V.S. Clure, (Eds.)., 1st Edn., Geological Society of London, London, ISBN-10: 1862390304, PP: 474.

Collinson, P., 1996. William tyndale and the course of the english reformation. Reformation, 1: 72-97

Dalrymple, R.W., 2010. Interpreting Sedimentary Successions: Facies, Facies Analysis and Facies 6 Models. In: Facies Models 4. James, N.P. and R.W. Dalrymple, (Eds.)., Geological Association of Canada, St. John's Newfoundland, pp: 3-18.

Delteil, J.R., J. Le Fournier and J. Micholet, 1975. Schéma d'évolution sédimentaire d'une marge continentale stable: Exemple type du golfe de Guinée, de l'Angola au Cameroun. IXè Congrès International de Sédimentologie. Thème, 4: 91-97.

Dickson, W.G., A. Danforth and M. Odegard, 2003. Gravity signatures of sediment systems: predicting reservoir distribution in Angolan and Brazilian basins. Geol. Society London Special Publicat., 207: 241-256.

DOI: 10.1144/GSL.SP.2003.207.12

Dumort, J. C., 1968. Explanatory notice of the sheet Douala west. Geological recognition map at scale 1/500,000. Department Mines Geol., Cameroon, 1: 69-69. 
Eriksson, P.G., K.C. Condie, H. Trisgaard, W. Muller and J. Chiarenzali et al., 1998. Precambrian clastic sedimentation systems. Sedimentary Geol., 120: 553. DOI: 10.1016/S0037-0738(98)00026-8

Fisher, R.V., 1971. Features of coarse-grained, highconcentration fluids and their deposits. J. Sedimentary Petrol., 41: 916-927.

Ghibaudo, G., 1992. Subaqueous sediment gravity flow deposits: Practical criteria for their field description and classification. Sedimentology, 39: 423-454. DOI: 10.1111/j.1365-3091.1992.tb02126.x

Gugliotta, C., M. Agate and A. Sulli, 2013. Sedimentology and sequence stratigraphy of wedgetop clastic successions: Insights and open questions from the upper Tortonian Terravecchia Formation of the Scillato Basin (central-northern Sicily, Italy). Marine Petroleum Geol., 43: 239-259.

DOI: $10.1016 /$ j.marpetgeo.2013.02.004

Hamberg, L. and L.H. Nielsen, 2000. Shingled, sharpbased shoreface sandstones: Depositional response to stepwise forced regression in a shallow basin, upper Triassic Gassum Formation, Denmark. Geol. Society Special Publicat., 172: 69-89.

DOI: 10.1144/GSL.SP.2000.172.01.04

Harms, J.C., Southard, J.B., Spearing, D.R., Walker, R.G., 1995. Depositional environments as interpreted from primary sedimentary structures and stratification sequences. Society Econ. Paleontol. Mineral., 2: 161-161.

Hedberg, J.D., 1969. A geological analysis of the cameroon trend. Ph.D Thesis, Dissertation, Princeton University, Princeton.

Hjellbakk, A., 1997. Facies and fluvial architecture of a high-energy braided river: The upper proterozoic seglodden member, varanger peninsula, northern Norway. Sedimentary Geol., 114: 131-161. DOI: 10.1016/S0037-0738(97)00075-4

Johnson, H.D. and Baldwin, C.T., 1996. Shallow Clastic Seas. In: Sedimentary Environments: Processes, Facies and Stratigraphy, Reading, H.G. (Ed.)., Reprint, Wiley, Oxford, ISBN-10: 0632036273, pp: 688.

Kenfack, P.L., P.R. Njike Ngaha, G.E. Ekodeck and G. Ngueutchoua, 2012. Fossils dinoflagellates from the northern border of the Douala sedimentary sub-basin (South-West Cameroon): Age assessment and paleoecological interpretations. Geosciences, 2: 117-124.

DOI: $10.5923 /$ j.geo.20120205.03
Logar, J.F., 1983. Well evaluation conference. West Africa, Schlumberger Document, 1: 69-69.

Loule, J.P., S.E. Angoua Biouele, R. Seme Abomo and S. Tamfu, 1997. Timing of the communication between the South and central atlantic using palynological data from eight wells in the douala/kribi campo basin, Cameroon. Proceedings of the 2nd Annual Conference of IGCP Project 381, South Atlantic Mesozoic Correlations, Mar. 8-13, Cameroon, Yaoundé.

Lowe, D.R., 1982. Sediment gravity flows: II Depositional models with special reference to the deposits of high-density turbidity currents. J. Sedimentary Petrol., 52: 279-297.

Manga, C.S., 2008. Stratigraphy, structure and prospectivity of the southern onshore Douala Basin, Cameroon, Central Africa. Africa Geosci. Rev., 1: 13-37.

Mbesse, C.O., E. Roche and S. Ngos III, 2012. The Paleocene-Eocene boundary in the Douala Basin (Cameroon) Dinocysts biostratigraphy and tentative of Paleoenvironmental reconstruction. Geo-Eco-Trop., 36: 83-119.

Mclean, J.R. and T. Jerzykiewicz, 1978. Cyclicity, tectonics and coal: Some aspects of fluvial sedimentology in the Brazeau-Paskapoo Formations, Coal Valley area, Alberta, Canada. Dallas Geological Society, 5: 441-468.

Meyers, J.B., B.R. Rosendahl, H. Groschel-Becker, J.J.A. Austin and P.A. Rona, 1996. Deep penetrating MCS imaging of the rift-to-drift transition, offshore Douala and North Gabon basins, West Africa. Marine Petroleum Geol., 13: 791-835. DOI: 10.1016/0264-8172(96)00030-X

Miall, A.D., 1978. Lithofacies types and vertical profile models in braided river deposits: A summary. Memoir Canad. Society Petroleum Geol., 5: 859-859.

Miall, A.D., 1985. Architectural-element analysis: A new method of facies analysis applied to fluvial deposits. Earth Sci, Rev., 22: 261-308. DOI: $10.1016 / 0012-8252(85) 90001-7$

Miall, A.D., 1996. The Geology of Fluvial Deposits: Sedimentary Facies, Basin Analysis and Petroleum Geology. 1st Edn., Springer-Verlag, ISBN-10: 3540591869, pp: 582.

Mutti, E., R. Tinterri, D. Di Biase, L. Fava and N. Mavilla et al., 2000. Delta-front associations of ancient flood-dominated fluvio-deltaic systems. Revista Sociedad Geologica Espana, 13: 165-190. 
Nemec, W. and R.J. Steel, 1984. Alluvial and coastal conglomerates: Their significant features and some comments on gravelly mass-flow deposits. Sedimentol. Gravels Conglomerates-Memoir, 10: 1-31.

Nguene, F.R., S.F. Tamfu, J.P. Loule and C. Ngassa, 1992. Paleoenvironments of the Douala and Kribi/Campo subbasins, in Cameroon, West Africa. Explorat. Product. Elf Aquitaine, 13: 129-139.

Nichols, G., 2013. Sedimentology and Stratigraphy. 1st Edn., John Wiley and Sons, New York, ISBN-10: 1118687779, pp: 432.

Nilsen, T.H., 1982. Alluvial Fan Deposits. In: Sandstone Depositional Environments, Sholle, P.A. and D. Spearing, (Eds.)., AAPG, Tulsa, Okla, ISBN-10: 0891813071, pp: 410.

Njike Ngaha, P.R. and S.M. Eno Belinga, 1987. The Diachronism of the basal sandstone, paleoenvironment and the role of the opening of the South Atlantic. Ann. Faculty Sci. Earth Sci. Series, 1: 103-119.

Njike Ngaha, P.R., 1984. Contribution à l'étude géologique, stratigraphique et structurale de la bordure du bassin atlantique du Cameroun. Thèse 3 ème Cycle, Université de Yaoundé, Cameroun.

Njike Ngaha, P.R., 2005. Palynostratigraphie et reconstitution des paléoenvironnements du Crétacé de l'Est du basin sédimentaire de Douala (Cameroun). Thèse doctorat d'Etat. Univ. Yaoundé I, pp: 259.

Ntamak, N.M.J., B. Ketchemen Tandia, R.V. Ewane and J.P. Lissock, 2003. Etude sédimentologique des sédiments remaniés des localités de Sikoum et Loungahé: Sud-Est du Bassin de Douala, Cameroun. Ed. Rock View Ltd, Abuja Geocongress, pp: 103-108.

Ntamak, M.J.N., S. Bourquin, J.C. Makong, F. Baudin and G.M. Abolo et al., 2010. Sedimentology and sequence stratigraphy from outcrops of the KribiCampo sub-basin: Lower mundeck formation (lower cretaceous, southern Cameroon). J. African Earth Sci., 58: 1-18. DOI: 10.1016/j.jafrearsci.2010.01.004

Oliver, N.A. and S.W. Petters, 2013. Preliminary investigation of Late Turonian-Early Campanian shallow marine foraminifera of the Mungo River/Logbadjeck Formation, NW Douala Basin, Cameroon. African Earth Sci., 28: 1-1.

DOI: $10.1016 /$ j.jafrearsci.2013.11.003
Pauken, R.J., 1992. Sanaga Sud Field, Offshore Cameroon, West Africa. In: Giant Oil and Gas Fields of the Decade, Halbouty, M.T. (Ed.)., Memoir, pp: 217-230.

Postma, G., 1990. Depositional Architecture and Facies of River and Fan Deltas: A Synthesis. In: Coarsegrained Deltas Special Publications of International Association of Sedimentologist, Colella, A. and D.B. Prior, (Eds.)., John Wiley and Sons, Oxford, Boston, ISBN-10: 1444303864, pp: 368.

Reading, H.G. and J.D. Collinson, 1996. Clastic Coasts. In: Sedimentary Environments: Processes, Facies and Stratigraphy, Reading, H.G. (Ed.), John Wiley and Sons, Chichester, ISBN-10: 144431369X, pp: 704.

Reading, H.G., 2009. Alluvial Sediments. In: Sedimentary Environments: Processes, Facies and Stratigraphy. Blackwell Scientific, Reading, H.G. (Ed.)., John Wiley and Sons, Chichester, ISBN-10: 144431369X, pp: 704.

Regnoult, J.M., 1986. Synthèse Géologique du Cameroun. 1st Edn., Ministère des Mines et de l'Énergie, Yaoundé, Cameroun, pp: 119.

Rosendahl, B.R. and D.L. Scott, 1989. North Viking graben: An East African perspective. AAPG/Datapages Combined Publicat. Database, 73: 155-165.

Reyre, D., 1966. Histoire Géologique du Bassin de Douala. In: Symposium Sur Les Bassins Sédimentaires du Littoral Africain, Reyre, D. (Ed.)., Association du Service Géologique d'Afrique, IUGS, pp: 143-161.

Reyre, D., 1984. Remarques sur L'évolution Des Bassins Sédimentaires Africains de la Côte Atlantique. Bulletin de la Societé Géologique de France XXXVI, pp: 1041-1059.

Robertson, S., 1992. The biostratigraphy and palaeoenvironnement of seven wells from the Douala Basin, Cameroon. Recherche Exploration Production Elf-Aquitaine.

Salard, C.M., 1977. Paleopalynology of cameroon littoral sedimentary basin in its relations with the strati graphy and paleoecology. Ph.D. Thesis, Pierre and Marie Curie University, Paris.

Salard, C.M., 1979. Palynologie maastrichtienne et tertiaire du Cameroun. Etude qualitative et répartition vertical des principales espèces. Rev. Palaebotany Palynol., 28: 365-387. 
Salard, C.M., 1981. Palynologie maestrichtienne et tertiaire du cameroun. Resultats botaniques. Rev. Palaeobotany Palynol., 32: 401-439. DOI: $10.1016 / 0034-6667(81) 90021-\mathrm{X}$

Shanmugam, B., M. Poffenberger and J. Toro Alava, 2000. Tide-dominated estuarine facies in the Hollín and Napo ("T" and "U") formations (Cretaceous), Sacha field, Oriente basin, Ecuador. Am. Associat. Petroleum Geologists Bull., 84: 652-682.

Ghazi, S. and N.P. Mountney, 2009. Facies and architectural element analysis of a meandering fluvial succession: The Permian Warchha Sandstone, Salt Range, Pakistan. Sedimentary Geol., 221: 99-126. DOI: 10.1016/j.sedgeo.2009.08.002

Turner, P., 1980. Continental red beds. Developments in sedimentology. 1st Edn., Elsevier, Amsterdam, ISBN-10: 0080869424, pp: 561.
Wakefield, O.J.W. and N.P. Mountney, 2013. Stratigraphic architecture of back-filled incisedvalley systems: Pennsylvanian-permian lower cutler beds, UTAH, USA. Sedimentary Geol., 298: 1-16. DOI: 10.1016/j.sedgeo.2013.10.002.

Walker, R.G. and D.J. Cant, 1984. Facies model 3: Sandy braided systems. Geosci., Canada Reprint Services, 1: 23-31.

Walker, R.G., A.G. Plint, 1992. Wave and StormDominated Shallow Marine Systems. In: Facies Models: Response to Sea Level Change, Walker, H.G. and N.P. James, (Eds.)., Geological Association of Canada, Ontario, pp: 219-238. 